\title{
Longitudinal study of the effects of teat condition on the risk of new intramammary infections in dairy cows
}

\author{
V. Zoche-Golob, ${ }^{*} \dagger$ H. Haverkamp, ${ }^{*} \ddagger$ J.-H. Paduch, ${ }^{*}$ D. Klocke, ${ }^{*}$ C. Zinke, ${ }^{*}$ M. Hoedemaker,‡ W. Heuwieser, $\dagger$ \\ and V. Krömker*1 \\ *Department of Bioprocess Engineering - Microbiology, Faculty II, University of Applied Science and Arts, Heisterbergallee 12, 30453 Hannover, \\ Germany \\ †Clinic of Animal Reproduction, Department of Veterinary Medicine, Freie Universität Berlin, Königsweg 65, 14163 Berlin, Germany \\ ¥Clinic for Cattle, Stiftung Tierärztliche Hochschule Hannover, Bischofsholer Damm 15, 30173 Hannover, Germany
}

\begin{abstract}
Machine milking-induced alterations of teat tissue may impair local defense mechanisms and increase the risk of new intramammary infections. The objective of the current study was to assess the influence of short-term and long-term alterations of teat tissue and infectious status of the udder quarter on the risk of naturally occurring new intramammary infections, inflammatory responses, and mastitis. Short-term and long-term changes in teat condition of right udder quarters of 135 cows of a commercial dairy farm in Saxony-Anhalt, Germany, were recorded monthly for 10 mo using simple classification schemes. Quarter milk samples were collected from all examined quarters at each farm visit. Bacteriological culture results and somatic cell counts of quarter milk samples were used to determine new inflammatory responses (increase from $\leq 100,000$ cells $/ \mathrm{mL}$ to $>100,000$ cells $/ \mathrm{mL}$ between 2 samples), new infections (detection of a pathogen from a quarter that was free of the same pathogen at the preceding sampling), and new mastitis (combination of new inflammatory response and new infection). Separate Poisson mixed models for new inflammatory responses, new infections, and new mastitis caused by specific pathogens or groups of pathogens (contagious, environmental, major, minor, or any) were used to estimate risk ratios and $95 \%$ confidence intervals. Data preparation and parameter estimation were performed using the open source statistical analysis software R. We observed no effect of any variable describing teat condition on the risk of new intramammary infections, inflammatory responses, or mastitis. Intramammary infections of the same udder quarter in the preceding month did not affect risk either.
\end{abstract}

Key words: mastitis, udder health, hyperkeratosis, teat edema, risk factor

Received June 4, 2014.

Accepted October 28, 2014.

${ }^{1}$ Corresponding author: volker.kroemker@hs-hannover.de

\section{INTRODUCTION}

Mastitis is one of the most common health disorders in dairy cows (Egger-Danner et al., 2012). Infections with pathogenic bacteria entering the mammary gland via the teat canal are the most frequent cause of mastitis (O'Shea, 1987; GVA, 2012). Therefore, the condition of the teat as a barrier against infection is considered a major factor influencing the frequency of inflamed udder quarters (Mein, 2012). Machine milking-induced tissue alterations at the teat may impair local defense mechanisms (O'Shea, 1987; Mein, 2012). Mein et al. (2001) distinguished between short-term and long-term changes in teat condition. Short-term changes in teat condition are determined by tissue responses to a single milking such as congestion and edema. After cluster detachment, the teats should be dry, smooth, and pink (Krömker, 2007). Long-term changes in teat condition are the adaptation of the teat tissue to machine milking over weeks and are mainly defined by the degree of teat-end hyperkeratosis. Mein (2012) suggested that short-term changes inhibit timely closure of the teat canal orifice after milking and increase the risk of new intramammary infections (NIMI) by contagious as well as environmental mastitis pathogens. Due to the rough surface of a hyperkeratotic teat canal, more mastitis-causing bacteria can be found on the teat ends of teats with long-term changes. Such pathogens can more easily enter a teat canal with hyperkeratosis than a teat canal without hyperkeratosis (Neijenhuis et al., 2001b). A simple classification scheme to evaluate changes in teat condition for on-farm use has been developed (Mein et al., 2001). The evaluation includes color changes of the teat, swelling at the teat base and teat end, and callosity of the teat end. Only a few studies have investigated relationships between shortterm changes in teat condition and mastitis (Binde and Bakke, 1984; Zecconi et al., 1992; Zwertvaegher et al., 2013). Of these, only one studied naturally occurring NIMI as the dependent variable: Zecconi et al. (1992) could not show an association between changes in teat 
diameter as a measure of edema and infections with environmental pathogens. The results of observational studies evaluating associations between long-term changes in teat condition and mastitis are ambiguous (Haverkamp and Krömker, 2010).

Studies looking for associations between teat condition and NIMI are rare (Zadoks et al., 2001). However, reducing NIMI is crucial for improving udder health (Neave et al., 1969; Reyher et al., 2013). Therefore, evidence-based information about risk factors for NIMI is essential. Causal inference is only possible if the time series of occurrences can be clearly defined (Reyher et al., 2013). Longitudinal studies with repeated determinations of infectious status are needed to identify probable causes for NIMI but they are time consuming (Zadoks et al., 2001). The objective of the present study was to investigate possible associations between short-term and long-term changes in teat condition, infectious status, and naturally occurring NIMI with different pathogens and new inflammatory responses under field conditions in a longitudinal design.

\section{MATERIALS AND METHODS}

\section{Herd and Animals}

The study was conducted from May 2009 to February 2010 on a commercial dairy farm in Saxony-Anhalt, Germany. The farm kept, on average, 800 German Holstein cows housed in freestall barns. The cows were milked twice a day on a rotary parlor with 40 milking units and automated cluster removal (GEA Farm Technologies GmbH, Bönen, Germany). The milking machine was routinely checked according to ISO 5707:2007 (ISO, 2007) once a year. The farm was selected because of a high monthly incidence of udder inflammations based on DHI data in the preceding year (i.e., every month above the regional median of $21 \%$ ). Mean milk yield in 305 lactation days was $10,410 \mathrm{~kg}$ of ECM. Mean bulk milk SCC was 215,000 cells/mL at the beginning of the study.

All cows between 15 and 90 DIM at the first visit were included in the study unless they met one or more of the following exclusion criteria: cows that had already been treated because of mastitis in their current lactation, cows that had a SCC of more than 250,000 cells $/ \mathrm{mL}$ in the last DHIA test before initiation of the study, or cows that had fewer than 4 functional udder quarters. Cows with black teats on the right udder half were excluded to ensure accurate determination of teat color changes (Mein et al., 2001). Only the 2 right teats were examined because a careful examination of all 4 teats was not possible without disrupting the milking routine. All cows included in the study were examined monthly for 10 mo or until they were dried-off, sold, or culled.

\section{Data Collection}

During the 10 monthly visits, short-term and longterm changes in teat condition were determined, and quarter milk samples were taken by 2 trained investigators at the usual milkings of the herd. Illustrated scorecards were used, and teat condition of the first 5 cows was evaluated by the investigators together at first visit to obtain concordant results. Last calving date and current lactation number of the selected cows were taken from the herd management software.

Teat Condition. Short-term and long-term changes in teat condition were determined within 1 min of removal of the milking clusters according to Mein et al. (2001). Teats were examined visually and by manual palpation. Color changes of the teat skin were categorized as "pink," "reddened," or "blue." Swelling at or near the teat base was recorded as "normal" (mild swelling or slight lip mark of the liner mouthpiece) or as "ring" (palpable ring where the teat tissue had swollen into the liner mouthpiece chamber). The teat end was classified as "normal" (soft tissue without palpable swelling) or "swollen." Teat-end hyperkeratosis was described as no ring, a smooth ring, a rough ring, or a very rough ring around the teat orifice. The condition of every teat was documented, together with cow identification number, teat position (front right or hind right), and date of the farm visit.

Milk Samples. Quarter foremilk samples of the 2 right udder quarters of all cows included in the study were taken at each farm visit aseptically according to the guidelines of the German Veterinary Association (GVA, 2009) after routine udder preparation and disinfection of the teat ends with $70 \%$ alcohol. Udders were routinely prepared by farm personnel by milking of 2 or 3 streams per teat and cleaning the teats with spin-dried cotton cloths. Separate cotton cloths were used for each cow. Approximately $10 \mathrm{~mL}$ of milk was sampled into sterile plastic tubes with preservative Ly20 containing boric acid (Heeschen et al., 1969; GVA, 2009) and analyzed within $24 \mathrm{~h}$ in the microbiological laboratory of the University of Applied Science and Arts (Hannover, Germany).

Somatic cell counts of all milk samples were analyzed using flow cytometry (SomaScope Smart, Delta Instruments, Drachten, the Netherlands). Culturing of the milk samples and identification of the isolates were carried out according to National Mastitis Council and German Veterinary Association recommendations 
(Hogan et al., 1999; GVA, 2009). Briefly, $10 \mu \mathrm{L}$ of a well-mixed sample was streaked onto a quadrant of an esculin blood agar plate (Oxoid, Wesel, Germany). The plates were incubated aerobically and examined after 24 and $48 \mathrm{~h}$. Colonies were identified by Gram staining, cell morphology, hemolysis patterns, esculin hydrolysis, and catalase test. Presumptive Staphylococcus aureus were identified with Bactident Coagulase EDTA rabbit plasma (Merck, Darmstadt, Germany). Esculin-positive streptococci were subcultured on modified Rambach agar (Watts et al., 1993) to determine $\beta$-D-galactosidase activity. $\beta$-Hemolytic streptococci were further characterized via Lancefield serotyping (Diamondial Strep Kit, Diamondial, Sees, France). Streptococci from group B were referred to as Streptococcus agalactiae and those from group C as Streptococcus dysgalactiae. Grampositive, $\beta$-hemolytic, catalase-negative irregular rods with a V-or Y-shaped configuration were identified as Trueperella pyogenes. Coryneform bacteria form small colonies on esculin blood agar; they are gram-positive and catalase positive. Both Trueperella pyogenes and coryneform bacteria are asporogenic. Bacillus species form large colonies on esculin blood agar and are gram-positive, catalase positive, and capable of forming endospores. Coliform bacteria are gram-negative and cytochrome oxidase-negative (Bactident oxidase, Merck) rod-shaped bacteria, capable of fermenting glucose (OF basal medium with addition of $\mathrm{D}(+)$-glucose monohydrate, Merck). Presumptive coliform bacteria were subcultured on ChromoCult coliform agar (Merck) to differentiate between Escherichia coli and other coliform bacteria. Klebsiella species are immobile during the performance of the oxidation-fermentation test. Pseudomonads were identified as gram-negative, cytochrome oxidase-positive, rod-shaped bacteria that break down glucose oxidatively. Yeasts and Prototheca species were differentiated microscopically after subculture on YGC (yeast extract-glucose-chloramphenicol) agar (Merck).

Contagious pathogens (Staph. aureus, Strep. agalactiae, Strep. dysgalactiae, and Trueperella pyogenes) were reported if one or more colonies were found. Environmental (coliform bacteria and streptococci other than Strep. agalactiae and Strep. dysgalactiae) and minor pathogens (CNS, coryneform bacteria, and Bacillus spp.) were only reported if at least 5 colonies were found. Identified mastitis pathogens were grouped into contagious pathogens, environmental pathogens, and minor pathogens. Contagious and environmental pathogens were summarized as major pathogens and minor and major pathogens together as any pathogen. Samples were considered contaminated if more than 2 different colony types were isolated (Hogan et al., 1999).

\section{Data Preparation}

Data about lactations (lactation number, calving date), teat condition, mastitis pathogens, and SCC were merged in an Excel (Microsoft Corp., Redmond, WA) spreadsheet using one row per observation per udder quarter. The spreadsheet was imported to the statistical software R 3.0.2 (R Development Core Team, 2013) with which all statistical analyses were conducted.

New intramammary infections were defined as the isolation of a pathogen from a quarter that was free of that particular pathogen in the sample of the month before (Reyher et al., 2013). If the pathogen of interest had been isolated from the sample of the preceding month, the quarter was not at risk for a NIMI and the observation was excluded from analysis (Zadoks et al., 2001). If either of the 2 samples to define a NIMI was contaminated or missing, no decision was made and NIMI of that observation was treated as a missing value. A new infection with at least one pathogen of a group of pathogens (environmental, contagious, major, minor, or any) implied a NIMI with this group. New inflammatory responses (NFLAM) were defined correspondingly as a quarter having an SCC of $>100,000$ cells/mL in a sample and an SCC $\leq 100,000$ cells $/ \mathrm{mL}$ in the sample of the preceding month. A cut-off value of 100,000 cells $/ \mathrm{mL}$ was chosen to detect inflammatory responses of mammary glands (not IMI) according to the results of a meta-analysis of Djabri et al. (2002) and the guidelines of the German Veterinary Association (GVA, 2012) that a threshold of 100,000 cells $/ \mathrm{mL}$ is a suitable approximation to define uninflamed quarters. Combinations of NIMI and NFLAM were considered as new mastitis (NMAST; GVA, 2012). New mastitis was only determined for groups of pathogens (environmental, contagious, major, minor, or any).

Because time-series analysis is considered useful to discriminate between cause and effect, occurrence or nonoccurrence of NIMI, NFLAM, or NMAST at time $t$ were treated as dependent variables in statistical analyses; and teat condition and infectious and inflammatory status at time $t-1$ as independent variables (Zadoks et al., 2001). Infectious status in a previous sample; that is, presence of pathogens other than that used for defining the dependent variable, was used to assess whether interactions between infections with different pathogens existed as described by Lam et al. (1997) and Zadoks et al. (2001). Inflammatory status ( $\leq$ or $>100,000$ cells $/ \mathrm{mL}$ ), quarter position (front right or hind right), and lactation ( 1 or $\geq 2$ ) were also included in the analysis. To increase the number of observations per stratum, teat color and teat-end hyperkeratosis were used as dichotomous variables by categorizing them as "pink" and "not pink" and "at most a smooth 
ring" and "more than a smooth ring," respectively. Only complete observations per dependent variable; that is, without a missing value for any variable, were used for statistical analyses.

\section{Statistical Analysis}

Udder quarter within cow was the statistical unit. Separate analyses were run for NFLAM and NIMI considering single pathogens and groups of pathogens, and for NMAST considering only groups of pathogens as dependent variables. Combinations of variables with common intersections were excluded (e.g., NIMI with a major pathogen and isolation of Staph. aureus). Only combinations of dependent and independent variables were used in multivariable Poisson regression models in which all fields of a contingency table contained at least 5 observations. All models contained cow and quarter within cow as random effects to account for clustering within cow and repeated observations per quarter. Independent variables with common intersections were not included in the same model but tested in separate models. After selecting the model without interactions per dependent variable that fitted best to the data according to Akaike information criterion, all possible 2 -way interactions between the remaining independent variables were tested. For each dependent variable, the model with the lowest Akaike information criterion was chosen as the final model (Bolker et al., 2009). Model parameters of the generalized linear mixed models were estimated using the $\mathrm{R}$ package lme 4 version $1.0-5$ (Bates et al., 2013). Model assumptions of the final models were graphically checked by plotting deviance residuals against fitted values.

Using Poisson regression with dichotomous outcome and equal time at risk for all observations (1 mo), the effect of the independent variables can be quantified as a risk ratio (RR; Ospina et al., 2012). Risk ratios and corresponding $95 \%$ CI were computed as measures of effect. The effect of a risk factor was considered statistically significant if the $95 \%$ CI of its RR did not include 1.

\section{RESULTS}

At the first farm visit, 135 cows were included in the study. The observed frequencies of the used independent variables; that is, teat color changes, swelling at the teat base and teat end, teat-end hyperkeratosis, and infectious and inflammatory statuses can be found in Tables 1 and 2. Table 3 presents the observed frequencies of the dependent variables (i.e., NFLAM and NIMI by pathogen and NMAST by group of pathogens). Compared with hind right quarters, front right quarters had a decreased risk of NIMI with any pathogen $(\mathrm{RR}=0.7 ; 95 \% \mathrm{CI}: 0.46-0.94)$ and major pathogens $(\mathrm{RR}=0.4 ; 95 \% \mathrm{CI}: 0.21-0.85)$ but an increased risk of NFLAM $(\mathrm{RR}=1.6 ; 95 \% \mathrm{CI}: 1.17-2.10)$. Quarters with a preceding SCC $>100,000$ cells $/ \mathrm{mL}$ had a higher risk of NIMI with major pathogens than quarters with lower SCC (RR $=2.1 ; 95 \%$ CI: 1.07-4.04). Aside from these, no significant associations were found. None of the final regression models showed insufficient model fit. The final models with NIMI with contagious pathogens and Staph. aureus with NMAST caused by any pathogen as dependent variables did not include any fixed effects other than an intercept.

\section{DISCUSSION}

\section{Teat Condition}

To our knowledge, the present study is the first to evaluate associations between risk of NIMI and shortterm as well as long-term changes in teat condition. In our data set, no effects of any variable of short-term or long-term changes in teat condition on the risk of an udder quarter for NFLAM or any kind of NIMI or

Table 1. Variables of teat condition in 2,019 monthly observations of 135 cows

\begin{tabular}{|c|c|c|c|c|}
\hline Variable & \multicolumn{4}{|c|}{$\begin{array}{c}\text { Possible values } \\
\text { Frequency [no. }(\%)]\end{array}$} \\
\hline Quarter & $\begin{array}{l}\text { Hind right } \\
936(46.4)\end{array}$ & \multirow{6}{*}{$\begin{array}{c}\text { Reddened } \\
1,048(51.9)\end{array}$} & \multirow{2}{*}{\multicolumn{2}{|c|}{$\begin{array}{c}\text { Front right } \\
1,083(53.6) \\
\geq 2 \\
1,391(68.9)\end{array}$}} \\
\hline Lactation & $\begin{array}{c}1 \\
628(31.1)\end{array}$ & & & \\
\hline Teat color & $\begin{array}{c}\text { Pink } \\
233(11.5)\end{array}$ & & \multicolumn{2}{|c|}{$\begin{array}{c}\text { Blue } \\
738(36.6)\end{array}$} \\
\hline Teat base & $\begin{array}{c}\text { Normal } \\
1,336(66.2)\end{array}$ & & \multicolumn{2}{|c|}{$\begin{array}{l}\text { Ring } \\
683(33.8)\end{array}$} \\
\hline Teat end & $\begin{array}{c}\text { Normal } \\
1,024(50.7)\end{array}$ & & \multicolumn{2}{|c|}{$\begin{array}{l}\text { Swollen } \\
995(49.3)\end{array}$} \\
\hline Teat-end hyperkeratosis & $\begin{array}{lc}\text { No ring } & \text { Smooth ring } \\
65(3.2) & 686(34.0)\end{array}$ & & $\begin{array}{l}\text { Rough ring } \\
939(46.5)\end{array}$ & $\begin{array}{l}\text { Very rough ring } \\
329(16.3)\end{array}$ \\
\hline
\end{tabular}


Table 2. Detected mastitis pathogens and inflammatory responses in 2,019 monthly milk samples of the right udder quarters of 135 cows

\begin{tabular}{lc}
\hline Variable & $\begin{array}{c}\text { Frequency } \\
{[\text { no. }(\%)]}\end{array}$ \\
\hline Major pathogen & $248(12.3)$ \\
Contagious pathogen & $60(3.0)$ \\
Streptococcus agalactiae & $9(0.4)$ \\
Streptococcus dysgalactiae & $4(0.2)$ \\
Staphylococcus aureus & $44(2.2)$ \\
Trueperella pyogenes & $3(0.1)$ \\
Environmental pathogen & $190(9.4)$ \\
Other streptococci & $186(9.2)$ \\
Coliform bacteria & $4(0.2)$ \\
Minor pathogen & $413(20.5)$ \\
CNS & $151(7.5)$ \\
Coryneform bacteria & $270(13.4)$ \\
Bacillus spp. & $14(0.7)$ \\
Any pathogen & $601(29.8)$ \\
SCC $>100,000$ cells/mL & $786(38.9)$ \\
\hline
\end{tabular}

NMAST were present. Previous studies on the association between short-term changes in teat condition and mastitis did not use the scoring scheme by Mein et al. (2001) but instead used changes in teat diameter before and after milking (Zecconi et al., 1992; Zwertvaegher et al., 2013). Those authors interpreted an increase in teat diameter as a sign of edema. Teats with a relative increase in teat barrel diameter during milking had a higher SCC, whereas associations with new inflammatory responses were not evaluated in a recent study (Zwertvaegher et al., 2013). To our knowledge, only one publication (Zadoks et al., 2001) has evaluated the association between teat-end hyperkeratosis and NIMI during lactation. Teat-end roughness or teat-end callosity did not influence the incidence of infections with Strep. uberis (Zadoks et al., 2001). The risk of NIMI with Staph. aureus was only significantly higher in udder quarters with rough teat ends if corynebacteria were present simultaneously and in teats with extreme thick callosity rings around the orifice (Zadoks et al., 2001). In a study investigating NIMI during the dry period, quarters with cracked teat ends before drying-off had $70 \%$ higher odds of NIMI (Dingwell et al., 2004). The odds of isolation of a mastitis pathogen from a quarter milk sample increased with increasing teat-end callosity score of the corresponding teat (de Pinho Manzi et al., 2012). However, cows with mild and moderate teat-end callosity had a decreased risk of SCC >199,000 cells/ $\mathrm{mL}$ at the next milk recording compared with cows with normal teat ends, regardless of their SCC at the previous test-day (Breen et al., 2009a). Even very severe teat-end callosity did not increase a cow's risk of SCC

Table 3. New infections, inflammatory responses, and mastitis in 2,019 monthly observations of the right udder quarters of 135 cows

\begin{tabular}{|c|c|c|}
\hline Variable & $\begin{array}{l}\text { Observations } \\
\text { at risk (no.) }\end{array}$ & $\begin{array}{c}\text { Frequency in } \\
\text { observations } \\
\text { at risk [no. (\%)] }\end{array}$ \\
\hline \multicolumn{3}{|l|}{ New infection ${ }^{1}$ with } \\
\hline Major pathogen & 605 & $36(6.0)$ \\
\hline Contagious pathogen & 710 & $25(3.5)^{2}$ \\
\hline Streptococcus agalactiae & 734 & $6(0.8)$ \\
\hline Streptococcus dysgalactiae & 736 & $3(0.4)$ \\
\hline Staphylococcus aureus & 716 & $16(2.2)$ \\
\hline Trueperella pyogenes & 739 & $1(0.1)$ \\
\hline Environmental pathogen & 628 & $11(1.8)$ \\
\hline Other streptococci & 629 & $8(1.3)$ \\
\hline Coliform bacteria & 735 & $3(0.4)$ \\
\hline Minor pathogen & 582 & $93(16.0)^{2}$ \\
\hline CNS & 655 & $33(5.0)$ \\
\hline Coryneform bacteria & 654 & $57(8.7)$ \\
\hline Bacillus species & 732 & $6(0.8)$ \\
\hline Any pathogen & 512 & $125(24.4)^{2}$ \\
\hline New inflammatory response ${ }^{3}$ & 931 & $193(20.7)$ \\
\hline \multicolumn{3}{|l|}{ New mastitis ${ }^{4}$ caused by } \\
\hline Major pathogen & 423 & $9(2.1)$ \\
\hline Contagious pathogen & 507 & $7(1.4)$ \\
\hline Environmental pathogen & 425 & $2(0.5)$ \\
\hline Minor pathogen & 426 & $15(3.5)$ \\
\hline Any pathogen & 379 & $24(6.3)$ \\
\hline
\end{tabular}


$>199,000$ cells $/ \mathrm{mL}$ at the next test-day (Breen et al., 2009a). Quarters and cows with clinical mastitis had significantly higher teat-end callosity scores (Neijenhuis et al., 2001a), but only very severe teat-end hyperkeratosis was associated with an increased risk of clinical mastitis (Breen et al., 2009b). Until now, an effect of short-term changes in teat condition on NIMI has not been proven and only extreme long-term changes in teat condition seem to increase the risk of NIMI. Therefore, teat condition probably has only a minor effect on udder health compared with other factors.

\section{Preceding IMI and Inflammation}

Preceding IMI did not influence the risk of NFLAM, NIMI, or NMAST. In a meta-analysis, a significant protective effect of infections with minor pathogens on the risk of NIMI with major pathogens has been demonstrated (Reyher et al., 2012b). The overall effect, however, was due to the strong effects found in challenge studies, whereas results of observational studies were less distinct. Altogether, observational studies did not show a significant effect.

Udder quarters with an SCC $>100,000$ cells $/ \mathrm{mL}$ had a significantly higher risk of subsequent NIMI with major pathogens compared with quarters with lower SCC. A higher risk of NIMI caused by Staph. aureus after SCC $>500,000$ cells $/ \mathrm{mL}$ was also shown by Zadoks et al. (2001; investigating 100 NIMI by Staph. aureus). This was not true for NIMI caused by Strep. uberis (Zadoks et al., 2001; evaluating 93 NIMI by Strep. uberis). Analyzing a larger data set with 485 NIMI (258 Staph. aureus NIMI, 56 Strep. uberis NIMI, 49 Strep. dysgalactiae NIMI, and 122 coliform NIMI), Reyher et al. (2012a) reported significantly increased odds of NIMI with major pathogens (i.e., Staph. aureus, Strep. uberis, Strep. dysgalactiae, coliforms) with increasing previous SCC. It is plausible that the detected statistical effect of quarters with elevated SCC having an increased risk of NIMI with major pathogens was not a causal effect in the sense that an udder quarter with a SCC $>100,000$ cells/mL was more susceptible to NIMI by major pathogens for biological reasons (Reyher et al., 2012a). Instead, the infection probably began before the preceding sampling at which an increased SCC, but no major pathogens, was detected, triggering an inflammatory response. The increase of somatic cells in milk is a distinct sign of inflammation (Dohoo and Meek, 1982; NMC, 2001; Djabri et al., 2002; GVA, 2012). However, sensitivity and specificity of a threshold of 100,000 cells $/ \mathrm{mL}$ to detect IMI were estimated at only 83 and $81 \%$, respectively (Schepers et al., 1997). At this early stage of infection, the pathogen load in milk may have been below the detection limit of bacteriological culture. Therefore, the NIMI was only diagnosed 1 mo later.

The time difference between diagnosis of inflammatory response and of infection could impede the detection of NMAST by major pathogens when using our definition that a NMAST was only present when NIMI and NFLAM occurred simultaneously. In $58 \%$ of the observations with NIMI caused by major pathogens, a preceding inflammation existed. This might explain why NMAST by major pathogens was too rare to be used in Poisson regression models.

\section{Quarter Position}

Position of the udder quarter had different effects on NIMI with any or major pathogens and on NFLAM. Although front right quarters had a decreased risk of NIMI with any pathogen and major pathogens, their risk of NFLAM was higher compared with the hind right quarter. Front quarters seem to have a greater variability in SCC (Olde Riekerink et al., 2007) and produce less milk (e.g., Tančin et al., 2006) than hind quarters. This may explain the higher risk of increases from below to above 100,000 cells/mL that we observed in front quarters. The literature shows contradictory positions on whether specific udder quarters have an increased or decreased risk of mastitis (Reyher et al., 2013). Barkema et al. (1997) noted a lower risk of IMI and of an SCC $>250,000$ cells $/ \mathrm{mL}$ in front quarters compared with hind quarters of the same side. Zadoks et al. (2001) did not find any significant effects of quarter position on NIMI in multivariable models if teat condition was included. Reyher et al. (2013) could only show significant risk differences between left and right hind quarters and only for the risk of NIMI with Corynebacterium bovis. As we investigated cows of only one farm, our findings may result from farm-specific factors, which we did not observe.

\section{Limitations of the Study}

Although our final data set consisted of 2,019 observations in total, only a few observations with NIMI or NMAST by specific pathogens were available for analysis (Table 3), which limited our ability to identify significant associations. Only cows that were between 15 and 90 DIM at the first farm visit of the study were included because we aimed for a follow-up period of approximately one lactation (9 mo). Of the 135 cows, only 79 were observed until the end of the study period; 56 were dried-off, sold, or culled before completion of the study. Therefore, the available observations (set of milk sample, teat evaluation, and lactational data of a teat at a farm visit) were reduced from 2,700 to 2,434 . Due 
to failures of the electronic animal identification system in the milking parlor, 34 observations were missing. A further 381 observations were excluded because values of at least one independent variable were missing. Of the remaining 2,019 milk samples, 614 (30.4\%) were contaminated. The current study was conducted on a commercial farm with a rotary parlor. Due to the milking routine and the speed of the parlor, it was impossible to evaluate all 4 quarters. Therefore, we chose not to evaluate all 4 udder quarters of each cow and used only the right udder half, which was easier to reach when the cows were milked. No values of NFLAM, NIMI, and NMAST were available for the first farm visit because they depend on reports of 2 farm visits. Furthermore, 1 contaminated milk sample led to missing values of NIMI and NMAST of 2 visits.

Not all possible independent variables were used in Poisson regression models because of too few observations for sensible modeling of associations with dependent variables. In particular, NIMI with environmental pathogens (coliform bacteria and streptococci other than Strep. agalactiae and Strep. dysgalactiae) and NMAST caused by major pathogens were too rare to be analyzed. The geometric means of duration of IMI with coliforms and environmental streptococci were 9 and $17 \mathrm{~d}$, respectively (Smith et al., 1985). As the sampling interval was 1 mo, most infections with environmental pathogens were likely missed. We assume that the "true" incidence of IMI by environmental pathogens was higher than found in our data set.

Influence of stage of lactation on teat condition and on the risk of NFLAM, NIMI, and NMAST could not be investigated separately because all cows were at approximately the same DIM at every farm visit. Therefore, the effect of stage of lactation and the unobserved effects of each visit (e.g., changes of weather or forage quality) could not be separated. Neither Zadoks et al. (2001) nor Reyher et al. (2013) reported a significant effect of lactational stage on the risk or odds of NIMI, respectively. Adding a random effect variable for month of visit to account for clustering within month of visit caused negligible changes in parameter and standard error estimates without consequences for the interpretation. Models with this additional variable did not have lower values of Akaike information criterion than the corresponding models without. Thus, we used the less complex models.

\section{CONCLUSIONS}

Although reducing IMI is crucial for improving udder health, an evidence-based association between teat condition and risk of NIMI has not yet been established. In the present study, we could not show associations between teat condition and risk of NIMI. In particular, whether teat condition is a specific risk factor for a certain group of pathogens remains unclear. Data from this study suggest that if teat condition does influence the risk of NIMI, the effect would be small. Further longitudinal studies with shorter sampling intervals (1-2 wk) are warranted to evaluate potential causal relationships between teat condition and NIMI. Based on a similar incidence as in our data set and risk ratios of 1.5, a minimum of 150 NIMI per pathogen would be required and it would be a challenge to implement such a study on a commercial farm.

\section{ACKNOWLEDGMENTS}

The authors thank the personnel of LW Betrieb e. G. Selbitz (Selbitz, Germany) for the possibility to conduct the study and their help with the data collection. Special thanks go to M. Bilke and H. Rettel (LW Betrieb e. G. Selbitz) for their help at the farm visits. This study was funded partly by the SESAM project Saxony-Anhalt, EFRE (European Fund of Regional Development) and the federal state of Lower Saxony.

\section{REFERENCES}

Barkema, H. W., Y. H. Schukken, T. J. G. M. Lam, D. T. Galligan, M. L. Beiboer, and A. Brand. 1997. Estimation of interdependence among quarters of the bovine udder with subclinical mastitis and implications for analysis. J. Dairy Sci. 80:1592-1599. http:// dx.doi.org/10.3168/jds.S0022-0302(97)76089-2.

Bates, D., M. Maechler, B. Bolker, and S. Walker. 2013. lme4: Linear mixed-effects models using Eigen and S4. R package version 1.0-5. http://CRAN.R-project.org/package=lme 4 .

Binde, M., and H. Bakke. 1984. Relationships between teat characteristics and udder health. A field survey. Nord. Vet. Med. 36:111116.

Bolker, B. M., M. E. Brooks, C. J. Clark, S. W. Geange, J. R. Poulsen, M. H. H. Stevens, and J.-S. S. White. 2009. Generalized linear mixed models: A practical guide for ecology and evolution. Trends Ecol. Evol. 24:127-135. http://dx.doi.org/10.1016/j. tree.2008.10.008.

Breen, J. E., A. J. Bradley, and M. J. Green. 2009a. Quarter and cow risk factors associated with a somatic cell count greater than 199,000 cells per milliliter in United Kingdom dairy cows. J. Dairy Sci. 92:3106-3115.

Breen, J. E., M. J. Green, and A. J. Bradley. 2009b. Quarter and cow risk factors associated with the occurrence of clinical mastitis in dairy cows in the United Kingdom. J. Dairy Sci. 92:2551-2561.

de Pinho Manzi, M., D. B. Nóbrega, P. Y. Faccioli, M. Z. Troncarelli, B. D. Menozzi, and H. Langoni. 2012. Relationship between teat-end condition, udder cleanliness and bovine subclinical mastitis. Res. Vet. Sci. 93:430-434. http://dx.doi.org/10.1016/j. rvsc. 2011.05.010

Dingwell, R. T., K. Leslie, Y. Schukken, J. Sargeant, L. Timms, T. Duffield, G. Keefe, D. Kelton, K. Lissemore, and J. Conklin. 2004. Association of cow and quarter-level factors at drying-off with new intramammary infections during the dry period. Prev. Vet. Med. 63:75-89. http://dx.doi.org/10.1016/j.prevetmed.2004.01.012.

Djabri, B., N. Bareille, F. Beaudeau, and H. Seegers. 2002. Quarter milk somatic cell count in infected dairy cows: A meta-analysis. Vet. Res. 33:335-357. http://dx.doi.org/10.1051/vetres:2002021. 
Dohoo, I. R., and A. H. Meek. 1982. Somatic cell counts in bovine milk. Can. Vet. J. 23:119-125.

Egger-Danner, C., B. Fuerst-Waltl, W. Obritzhauser, C. Fuerst, H. Schwarzenbacher, B. Grassauer, M. Mayerhofer, and A. Koeck. 2012. Recording of direct health traits in Austria-Experience report with emphasis on aspects of availability for breeding purposes. J. Dairy Sci. 95:2765-2777.

GVA (German Veterinary Association). 2009. Leitlinien Entnahme von Milchproben unter antiseptischen Bedingungen und Isolierung und Identifizierung von Mastitiserregern. 2nd ed. Verl. der Dt. Veterinärmed. Ges., Gießen, Germany.

GVA (German Veterinary Association). 2012. Leitlinien zur Bekämpfung der Mastitis des Rindes als Bestandsproblem. 5th ed. Verl. der Dt. Veterinärmed. Ges., Gießen, Germany.

Haverkamp, H., and V. Krömker. 2010. Impaired teat condition as a risk factor for mastitis. Tierarztl. Prax. Ausg. G Grosstiere Nutztiere 38:297-304.

Heeschen, W., J. Reichmuth, A. Tolle, and H. Zeidler. 1969. Die Konservierung von Milchproben zur bakteriologischen, zytologischen und hemmstoffbiologischen Untersuchung. Milchwissenschaft 24:729-734.

Hogan, J. S., R. N. González, R. J. Harmon, S. C. Nickerson, S. P. Oliver, J. W. Pankey, and K. L. Smith. 1999. Laboratory Handbook on Bovine Mastitis. National Mastitis Council Inc., Madison, WI.

ISO (International Organization for Standardization). 2007. ISO 5707:2007: Milking machine installations - Construction and performance. ISO, Geneva, Switzerland.

Krömker, V. 2007. Euterkrankheiten. Pages 47-74 in Kurzes Lehrbuch Milchkunde und Milchhygiene. V. Krömker, ed. Parey, Stuttgart, Germany.

Lam, T. J., Y. H. Schukken, J. H. van Vliet, F. J. Grommers, M. J. Tielen, and A. Brand. 1997. Effect of natural infection with minor pathogens on susceptibility to natural infection with major pathogens in the bovine mammary gland. Am. J. Vet. Res. 58:17-22.

Mein, G. A. 2012. The role of the milking machine in mastitis control. Vet. Clin. North Am. Food Anim. Pract. 28:307-320.

Mein, G. A., F. Neijenhuis, W. F. Morgan, D. J. Reinemann, J. E. Hillerton, J. R. Baines, I. Ohnstad, M. D. Rasmussen, L. Timms, J. S. Britt, R. Farnsworth, N. Cook, and T. Hemling. 2001. Evaluation of bovine teat condition in commercial dairy herds - non-infectious factors. Pages 357-351 in Proc. 2nd Int. Symp. Mastitis and Milk Quality. National Mastitis Council Inc., Madison, USA.

National Mastitis Council (NMC). 2001. Guidelines on normal and abnormal raw milk based on somatic cell counts and signs of clinical mastitis. National Mastitis Council Inc., Madison, WI.

Neave, F. K., F. H. Dodd, R. G. Kingwill, and D. R. Westgarth. 1969. Control of mastitis in the dairy herd by hygiene and management. J. Dairy Sci. 52:696-707.

Neijenhuis, F., H. W. Barkema, H. Hogeveen, and J. P. Noordhuizen. 2001a. Relationship between teat-end callosity and occurrence of clinical mastitis. J. Dairy Sci. 84:2664-2672.

Neijenhuis, F., K. de Koning, H. Barkema, and H. Hogeveen. 2001b. The effects of machine milking on teat condition. Pages 33-40 in Physiological and Technical Aspects of Machine Milking. A. Rosati, S. Mihina, and C. Mosconi, ed. International Committee for Animal Recording (ICAR), Rome, Italy.

O'Shea, J. 1987. Machine milking and mastitis. Section 2: Machine milking factors affecting mastitis-A literature review. Bull. Int. Dairy Fed. 215:5-32.
Olde Riekerink, R. G. M., H. W. Barkema, W. Veenstra, F. E. Berg, H. Stryhn, and R. N. Zadoks. 2007. Somatic cell count during and between milkings. J. Dairy Sci. 90:3733-3741. http://dx.doi. org/10.3168/jds.2007-0001.

Ospina, P. A., D. V. Nydam, and T. J. DiCiccio. 2012. Technical note: The risk ratio, an alternative to the odds ratio for estimating the association between multiple risk factors and a dichotomous outcome. J. Dairy Sci. 95:2576-2584. http://dx.doi.org/10.3168/ jds.2011-4515.

R Development Core Team. 2013. R: A language and environment for statistical computing. R Foundation for Statistical Computing. Vienna, Austria. http://www.R-project.org/.

Reyher, K. K., I. R. Dohoo, and C. A. Muckle. 2013. Evaluation of clustering of new intramammary infections in the bovine udder, including the impact of previous infections, herd prevalence, and somatic cell count on their development. J. Dairy Sci. 96:219-233. http://dx.doi.org/10.3168/jds.2012-5746.

Reyher, K. K., I. R. Dohoo, D. T. Scholl, and G. P. Keefe. 2012a. Evaluation of minor pathogen intramammary infection, susceptibility parameters, and somatic cell counts on the development of new intramammary infections with major mastitis pathogens. J. Dairy Sci. 95:3766-3780. http://dx.doi.org/10.3168/jds.2011-5148.

Reyher, K. K., D. Haine, I. R. Dohoo, and C. W. Revie. 2012b. Examining the effect of intramammary infections with minor mastitis pathogens on the acquisition of new intramammary infections with major mastitis pathogens-A systematic review and metaanalysis. J. Dairy Sci. 95:6483-6502. http://dx.doi.org/10.3168/ jds.2012-5594.

Schepers, A. J., T. J. Lam, Y. H. Schukken, J. B. Wilmink, and W. J. Hanekamp. 1997. Estimation of variance components for somatic cell counts to determine thresholds for uninfected quarters. J. Dairy Sci. 80:1833-1840.

Sergeant, E. S. G. 2014. Epitools epidemiological calculators. AusVet Animal Health Services and Australian Biosecurity Cooperative Research Centre for Emerging Infectious Disease. Accessed May 8, 2014. http://epitools.ausvet.com.au.

Smith, K. L., D. A. Todhunter, and P. S. Schoenberger. 1985. Environmental mastitis: cause, prevalence, prevention. J. Dairy Sci. 68:1531-1553.

Tančin, V., B. Ipema, P. Hogewerf, and J. Mačuhová. 2006. Sources of variation in milk flow characteristics at udder and quarter levels. J. Dairy Sci. 89:978-988. http://dx.doi.org/10.3168/jds.S00220302(06)72163-4.

Watts, J. L., A. Salmon, and R. J. Yancey Jr. 1993. Use of modified Rambach agar to differentiate Streptococcus uberis from other mastitis streptococci. J. Dairy Sci. 76:1740-1743.

Zadoks, R. N., H. G. Allore, H. W. Barkema, O. C. Sampimon, G. J. Wellenberg, Y. T. Gröhn, and Y. H. Schukken. 2001. Cow- and quarter-level risk factors for Streptococcus uberis and Staphylococcus aureus mastitis. J. Dairy Sci. 84:2649-2663.

Zecconi, A., J. Hamann, V. Bronzo, and G. Ruffo. 1992. Machineinduced teat tissue reactions and infection risk in a dairy herd free from contagious mastitis pathogens. J. Dairy Res. 59:265-271.

Zwertvaegher, I., S. De Vliegher, B. Verbist, A. Van Nuffel, J. Baert, and S. Van Weyenberg. 2013. Short communication: Associations between teat dimensions and milking-induced changes in teat dimensions and quarter milk somatic cell counts in dairy cows. J. Dairy Sci. 96:1075-1080. http://dx.doi.org/10.3168/jds.20125636. 